\title{
L-mvc, GST Ml genetic polymorphism and hepatocellular carcinoma risk among chronic hepatitis B carriers
}

\author{
Ling-Ling Hsieh",*. Ren-Chang Huangh, Ming-Whei Yuc, Chien-Jen Chen', Yun-Fan Liaw

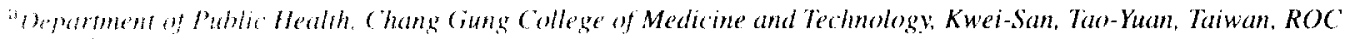

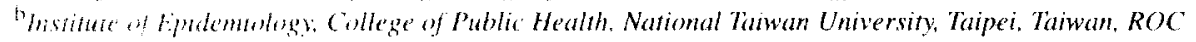

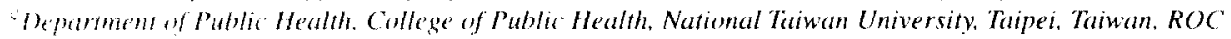

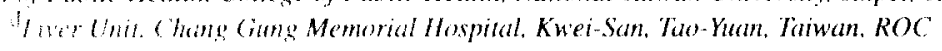

Received 25 January 1996; accepted 5 March 1990

\begin{abstract}
In order to assess asseciations between the genetic polymorphism of L-my and glutathione $S$-transferase M1 (GST M1) and the rish of hepatocetlular carcinoma (HCC). at total of 46 surgically treated HCC patients who were seropositive in hepa:tis: B surtike antigen (HBsAg) and 88 HBSAg-positive controls were recruited for this study. L-myc and GST M1 genetic polymorphism was examined using a polymerase chain reaction-based restriction fragment length polymorphism assay on DA extrated from liver and peripheral hlood samples. There was no significant difference in GST M1 genotypes between HCC paticnts and matched controls. A gene dosage trend of association with HCC risk was observed for L-myc genotype. The these-remponse relationship remained statistically significant in the multiple logistic regression analysis.
\end{abstract}

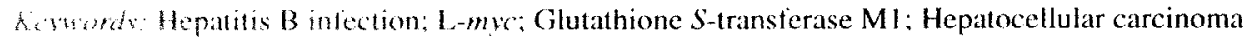

\section{Introduction}

Hepatocellular carcinoma (HCC) is the leading catuse of cancer death in Tawan, accounting for approximately 4465 deaths per year $\mid 11$ | This means that approximately $21.3 \%$ of all cancer deaths in Taisan are due to HCC. Epidemiological studies have suggested that environmental factors play a major role in the development of HCC [27]. Such factors include hepatitis virus infection, exposure to bemical carcinogens such as aflatoxin and cigarette

" Corresponding author smoking, and hormone levels. However, the molecular mechanism of how these factors are related to the development of HCC remains to be elucidated.

The induction of cancers in humans and in animals proceeds through a complex series of reactions and processes, subject to and controlled by a number of modifying factors. As a result, individual susceptibility to cancer is due to a combination of several factors. including differences in metabolism. DNA repair. altered proto-oncogene or tumor suppressor gene expression, hormonal, immunologic and nutritional status. Thus, susceptibility is probably the single most important factor relative to initiation of xenobiotic-induced eancer, as evidenced by the rela- 
tively small percentage of people who develop cancer in an exposed cohort.

Genetic susceptibility to chemically induced HCC determines the propensity to convert hepatocarcinogenic chemicals into active metabolites and to detoxify active metabolites by glutathione conjugation. The glutathione $S$-transferases (GSTs) are a unique group of multifunctional isozymes which catalyze the conjugation of reduced glutathione (GSH) with a variety of electrophilic compounds, including carcinogens and cytotoxic drugs [7]. In humans, this supergene family is divided on the basis of chromosomal location and sequence homology, into four classes named $\alpha, \mu, \pi$ and $\theta$ [16]. Within the GST $\mu$ family, one member, the GST M1 enzyme has been shown to catalyze the conjugation of potentially cytoand genotoxic epoxides such as aflatoxin $\mathrm{B}_{1}\left(\mathrm{AFB}_{1}\right)$ 8,9 -epoxide [17]. It has been shown that a deficiency of GST M1 enzyme activity is associated with a null genotype at this gene locus [20]. A series of reports suggested that the GST M1 null genotype/phenotype is associated with susceptibility to cancer, especially to cancer related to cigarette smoking $[10,14$, $19,21]$.

Activating proto-oncogenes, and turning them into oncogenes, is an important mechanism of tumor initiation and progression [2]. A series of reports suggested that allelic variants of proto-oncogenes, such as $\mathrm{H}$-ras and L-myc, might predispose individuals towards tumor development [3,18,23-25], although the hypothesized relationship between allelic variants of proto-oncogenes and cancer susceptibility does not yet have a mechanistic basis. Therefore, alleles of pro-oncogenes may serve as markers of genetic susceptibility to cancer. Recently, a study, based on a small number of HCC cases, has suggested that persons with the SS genotype of L-myc may be protected against $\mathrm{HCC}$ [25].

In this study, we have examined the relationship between the homozygous null genotype of GST M1, hepatitis $\mathrm{B}$ virus infection and L-myc genotype in the development of HCC.

\section{Materials and methods}

\subsection{Design of the case-control study}

Seventy HCC patients at Lin-Kou Chang Gung
Memorial Hospital from September 1990 to September 1992 were recruited as the case group. Most $(54 / 70=77 \%)$ of them were chronic carriers of hepatitis B surface antigen ( $\mathrm{HBsAg}$ ). Among them, 85.2\% (46) of HBsAg-positive HCC cases were male. A total of 88 male $\mathrm{HBsAg}$ carriers who were frequency-matched with $\mathrm{HCC}$ cases on age were also recruited as the control group.

High molecular weight DNA was purified from surgically removed non-tumor tissues for the cases and from the peripheral blood samples of the healthy controls by digestion with proteinase $K$ and extraction with phenol/chloroform, as described $[9,15]$.

\subsection{PCR analysis of GST MI genotype}

A simple assay based on PCR technology has been developed [8] to determine the presence or absence of GST M1. The following approach was used in this study: briefly, genomic DNA $(1 \mu \mathrm{g})$ was added to a PCR mix containing $200 \mathrm{ng}$ of each primer for GST MI (5'-CTGCCCTACTTGATTGATGGG-3' and 5'-CTGGATTGTAGCAGATCATGC-3') and $\beta$-globin (5'-ACACAACTGTGTTCACTAGC- $3^{\prime}$ and 5'-CAACTTCATCCACGTTCACC-3') as the internal control, $80 \mathrm{mM}$ dNTP, 1 unit of Taq polymerase (Promega Corp., Madison, WI, USA) and PCR buffer in a total volume of $25 \mu \mathrm{l}$. The PCR products were electrophoresed on $8 \%$ polyacrylamide gels, stained with ethidium bromide and photographed under UV light.

\subsection{PCR analysis of $L-m y c$ genotype}

An EcoRI polymorphism of the L-myc protooncogene is located in the second intron [13]. Genomic DNA was therefore amplified using primers that flank the polymorphic EcoRI site in the gene as described [25]. Genomic DNA $(1 \mu \mathrm{g})$ was added to a PCR mix containing $200 \mathrm{ng}$ of each primer (5'AGCAGAGCTCACCCAATAGG- $3^{\prime}$ and $5^{\prime}$-CCATTGTGTGGACAATCGCAT- $3^{\prime}$ ), $40 \mathrm{mM}$ dNTP, 1 unit of Taq polymerase and PCR buffer in $25 \mu 1$. The PCR products were purified with ammonium acetate and isopropanol, digested with EcoRI at $37^{\circ} \mathrm{C}$ overnight, electrophoresed on $8 \%$ polyacrylamide gels, stained with ethidium bromide and photographed under UV light. 


\subsection{Serological analysis for hepatitis virus infection}

Serological analysis for hepatitis $\mathrm{B} / \mathrm{C}$ virus infection was carried out as previously described [22]. $\mathrm{HBsAg}$ was analyzed using commercially available RIA kits (Abbott Laboratories, Chicago). Anti-HCV was assayed using a commercial available EIA (Abbott HCV EIA). Initially, reactive serum specimens were retested in duplicate and repeatedly reactive samples were defined as possibly positive. Positive samples were considered as true positive if confirmed by the more specific second-generation assay using synthetic peptides from both core and nonstructural regions of $\mathrm{HCV}$ (UBI HCV EIA; United Biomedical, New York).

\subsection{Statistical analysis}

Statistical analysis was done using $\chi^{2}$ test with or without Yate's correction, Fisher's exact test, and logistic regression analysis when appropriate.

\section{Results}

\subsection{Characteristics of HCC cases and controls}

The mean age \pm standard deviation were $47.3 \pm$ 12.8 for HBsAg-positive $\mathrm{HCC}$ cases and $50.8 \pm 11.3$ for age-matched healthy HBsAg carriers in the present study. Anti-HCV was detected in $6.5 \%(3 / 46)$ of HBsAg-positive HCC cases and in $0 \%(0 / 88)$ of healthy HBsAg carriers.

\section{$\therefore 2$ GST MI genotype and $H C C$.}

Fig. I shows the 273 bp DNA fragment amplified from the exon 4-5 region of GST M1 in subjects classified as GST M1 positive. Examples of GST MI null genotype, identified by the absence of this fragment, are also shown. Amplification of the $100 \mathrm{bp}$ fragment from the $\beta$-globin gene that served as internal control was observed in all subjects studied (Fig. $1)$

Table i shows the distribution of the GST M1 genotypes detected in these study groups. The frequency of GST MI null genotype in the HBsAgpositive HCC cases as compared with that in the healthy HBsAg carriers was not significantly differ-
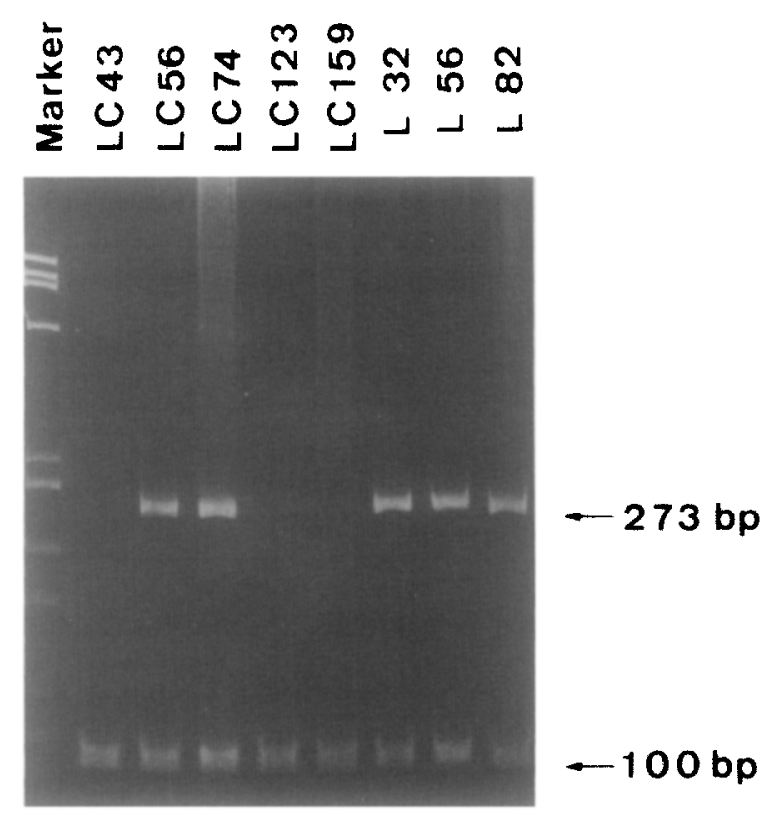

Fig. 1. Representative PCR-RFLP analysis of the GSI Ml gene on the HCC patients and controls. Samples of DNA were amplified using PCR, electrophoresed in polyacrylamide gels, and stained with ethidium bromide. The 273-bp DNA fragment corresponds to the GST M1, while the 100-bp DNA fragment corresponds to the $\beta$-globin gene as the internal control.

ent. The odds ratio was 1.0 (95\% confidence interval (CI) $0.5-2.3$ ).

\subsection{L-myc genotype and HCC}

The polyacrylamide gel band patterns for each Lmyc EcoRI genotype are shown in Fig. 2. Based on PCR and EcoRI digestion, two alleles are apparent: a $145 \mathrm{bp}$ fragment corresponding to the ' $\mathrm{L}$ ' allele which lacks the EcoRI site, and paired $104 \mathrm{bp}$ and $41 \mathrm{bp}$ fragments from the ' $\mathrm{S}$ ' allele, produced from the cut at the EcoRI site. The three genotypes are LL (145 bp fragment only), LS (145 bp, $104 \mathrm{bp}$, and $41 \mathrm{bp}$ fragments) and SS (104 bp and 41 fragments only).

Among the healthy HBsAg carriers, the distribution of L-myc genotype was LL $25.0 \%$ (22/88), LS $44.3 \%$ (39/88), and SS 30.7\% (27/88) (Table 1). Among HBsAg-positive HCC cases, the distribution of L-myc genotype was LL $41.3 \%$ (19/46), LS $41.3 \%$ (19/46), and SS $17.4 \%$ (8/46). Although this distribution does not differ significantly from that of the 
Table 1

The distribution of L-myc and GST M1 genotypes in HCC cases and controls

\begin{tabular}{lrll}
\hline Genotype & $\begin{array}{l}\text { HCC cases } \\
\text { No. (\%) }\end{array}$ & $\begin{array}{l}\text { Controls } \\
\text { No. (\%) }\end{array}$ & $\begin{array}{l}\text { Odds ratio } \\
(95 \% \text { CI })\end{array}$ \\
\hline L-myc & & & \\
SS & $8(17.4)$ & $27(30.7)$ & 1.0 \\
LS & $19(41.3)$ & $39(44.3)$ & $1.6(0.6-4.8)$ \\
LL & $19(41.3)$ & $22(25.0)$ & $2.9(1.0-9.0)$ \\
GST M1 & & & \\
Non-null & $21(45.7)$ & $41(46.6)$ & 1.0 \\
Null & $25(54.3)$ & $47(53.4)$ & $1.0(0.5-2.3)$ \\
\hline
\end{tabular}

controls $\left(\chi^{2}=4.7, P=0.096\right)$, a gene dosage trend was observed ( $P=0.04$ based on trend test). The odds ratio was $1.6(95 \% \mathrm{CI}=0.6-4.8)$ for $\mathrm{LS}$ genotype and $2.9(95 \% \mathrm{CI}=1.0-9.0)$ for the LL genotype, respectively. A similar gene dosage trend has only been observed for age groups younger than
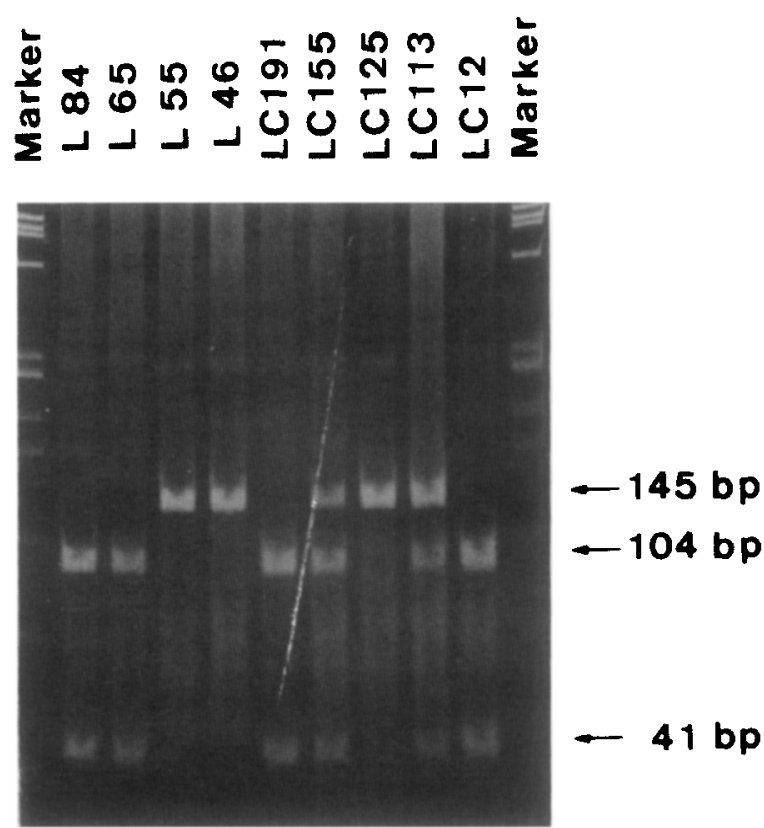

Fig. 2. Representative PCR-RFLP analysis of the L-myc gene on the HCC patients and controls. Samples of DNA were amplified using PCR, digested with EcoRI, electrophoresed in polyacrylamide gels, and stained with ethidium bromide. The 145-bp DNA fragment corresponds to the $\mathrm{L}$ allele which does not have an EcoRI site, while the paired 104-bp and 41-bp fragments correspond to the $S$ allele which has the EcoRI site.
Table 2

Odds ratios and $95 \%$ confidence interval for LS and LL genotype of L-myc gene according to age, and GST MI status

\begin{tabular}{lllll}
\hline Variables & \multicolumn{2}{l}{ Odds ratio (95\% confidence interval) } & $\begin{array}{l}P \\
\text { value }\end{array}$ & \\
\cline { 2 - 4 } & $\begin{array}{l}\text { SS } \\
\text { (referent) }\end{array}$ & LS & LL & \\
\hline Age & & & & \\
$\leqq 50$ & 1.0 & $2.5(0.6-11.2)$ & $4.5(0.9-23.0)$ & 0.045 \\
$>50$ & 1.0 & $0.8(0.2-4.8)$ & $1.8(0.3-9.8)$ & 0.530 \\
& & & & \\
GST M1 & & & & 0.277 \\
Null & 1.0 & $0.9(0.2-4.2)$ & $2.1(0.5-9.3)$ & 0.270 \\
Non-null & 1.0 & $3.1(0.6-17.0)$ & $4.4(0.7-30.0)$ & 0.099 \\
\hline
\end{tabular}

50 years but not in age groups over 50 years or either type of GST M1 group (Table 2).

To fully evaluate the factors affecting an individual who has HCC, logistic regression was used. After correction for the effects of age and GST M1 genotype, the LL genotype of L-myc remained significantly related to HCC with an odds ratio of 3.1 (95\% CI 1.8-5.1) (Table 3). However, the GST M1 genotype was not found to be associated with HCC.

\section{Discussion}

Chronic hepatitis virus infection has long been suggested to play a major role in the development of HCC [5]. In this study, $70 \mathrm{HCC}$ patients at Lin-Kou Chang Gung Memorial Hospital from September

Table 3

Logistic regression analysis of multiple risk factors of $\mathrm{HCC}$

\begin{tabular}{lll}
\hline Variables & Odd ratios & $95 \% \mathrm{CI}$ \\
\hline L-myc genotype & & \\
SS & 1.0 & $1.1-2.9$ \\
LS & 1.8 & $1.8-5.1$ \\
LL & 3.1 & \\
& & \\
GST M1 genotype & & $0.4-2.0$ \\
Null & 1.0 & \\
Non-null & 0.9 & \\
Age (years) & & $0.8-3.7$ \\
$>50$ & 1.0 & \\
$\leqq 50$ & 1.8 & \\
\hline
\end{tabular}


1990 to September 1992 were recruited as the case group. Among them, $77.1 \%$ were carriers of HBsAg. This percentage is similar to the HBsAg carrier rate of $\mathrm{HCC}$ exposure in Taiwan $(83.5 \%)$ reported previously [4]. The male/female sex ratio was $4.8(58 / 12)$. This ratio is close to previous reports [27]. Anti-HCV was detected in $18.6 \%(13 / 70)$ of the HCC cases, which is also consistent with previous reports $[6,26]$. A final of 46 male HBsAg-positive $\mathrm{HCC}$ cases were selected for the present study. A total of 88 healthy male HBsAg carriers who were matched with $\mathrm{HCC}$ cases on age were also recruited as the control group.

Increasing attention has recently been paid to the role of individual susceptibility in the pathogenesis of cancer. Recent studies suggest that GST MI and L$m y c$ genotype may be important indicators of genetic susceptibility to cancer. This case-control study shows a gene dosage trend of L-myc genotype association with $\mathrm{HCC}$. Compared to the healthy $\mathrm{HBsAg}$ carriers, $\mathrm{HBsAg}$-positive $\mathrm{HCC}$ cases have 1.6 and 2.9 the odds of carrying the LS and LL genotype, respectively. These findings are similar to other reports linking L-myc genotype with cancer susceptibility including HCC [25]. A similar gene dosage trend has only been found in age groups younger than 50 years groups but not in age groups over 50 years or either type of GST M1 group. These observations suggest that I.-myc genotype is a useful genetic susceptibility marker of $\mathrm{HCC}$.

Logistic regression was used to fully evaluate the factors affecting an individual with $\mathrm{HCC}$. After the effects of age and GST MI genotype have been corrected for. the LL genotype of $\mathrm{L}$-myc was still significantly related to $\mathrm{HCC}$ with an odds ratio of 3.1 (95\% CI $1.8-5.1)$.

Two possible explanations can be proposed for these findings. The first is a selection bias as individuals who were not surgical candidates had been excluded from this study. An alternative explanation is that HBsAg-positive individuals with the LL genotype are more susceptible to develop HCC. I$m y c$, expressed both in normal liver tissue and in liver tumors [12], appears to be a plausible candidate as a susceptibility gene. However, a functional difference between the proteins encoded by $\mathrm{S}$ and $\mathrm{L}$ alleles and the role of $\mathrm{L},-m y c$ in $\mathrm{HCC}$ has not yet been described. It is also possible that the polymorphism of L-my might has no biological effect except as a marker in linkage disequilibrium with an as yet unknown susceptibility gene.

Moreover, the frequency of GST M1 null genotype in the HBsAg-positive HCC cases compared with that found for the healthy HBsAg carriers was not significantly different. The percentage of GST M1 null genotype in this control group is similar to that reported in a previous study on the Taiwanese population [1]. Since the major function of the GST M1 enzyme is to catalyze the conjugation of epoxides of polycyclic aromatic hydrocarbons, aflatoxins and other compounds. This enzyme can serve as a valid susceptibility marker only if the exposure to environmental carcinogens is known. However, we did not have this information available for this study. Further epidemiological study designs are needed to elucidate the role of GST M1 on the development of HCC.

\section{Acknowledgements}

This study was supported by NSC grant NSC 842331-B182-066 and Chang Gung Medical Research Grant CMRP360.

\section{References}

[1] Bell, D.A., Thompson, C.L., Taylor, J., Miller, C.R., Perera, F., Hsich, L.L. and Lucier, G.W. (1992) Genetic monitoring of human polymorphic cancer susceptibility genes by polymerase chain reaction: application to glutathione transferase m. Environ. Health Perspect., 98, 113-117.

[2] Bishop, J.M. (1991) Molecular themes in oncogenesis. Cell, $64,235-248$.

[3] Champeme, M.H., Bieche, I., Latil, A., Hacene, K. and Lidereau, R. (1992) Association between restriction fragment length polymorphism of the L-myc gene and lung metastasis in human breast cancer. Int. J. Cancer, 50, 6-9.

[4] Chen, C.J., Liang, K.Y., Chang, A.S., Chang, Y.C., Lu, S.N., Liaw, Y.F., Chang, W.Y., Sheen, M.C. and Lin, T.M (1991) Effects of hepatitis B virus, alcohol drinking, cigarette smoking, and familial tendency on hepatocellular carcinoma. Hepatology, 13, 398-406.

[5] Chen, D.S. (1993) From hepatitis to hepatoma: lessons from type B viral hepatitis. Science, 262, 369-370.

[6] Chen, D.S., Kuo, G., Sung, J.L., Lai, M.Y., Sheu, J.C., Chen, P.J., Yang, P.M., Isu, H.M., Chang, M.H., Chen, C.J., Hahn, L.C., Choo, Q.L., Wang, T.H. and Houghton, M. (1990) Hepatitis $C$ virus infection in an area hyperendemic of hepatitis $B$ and chronic liver disease: the Taiwan experience. J. Infect. Dis., 162, 817-822.

[7] Coles, B. and Ketterer, B. (1990) The role of glutathione and 
glutathione transferases in chemical carcinogenesis. Crit. Rev. Biochem. Mol. Biol., 25, 47-70.

[8] Comstock, K.E., Sanderson, B.J.S., Claflin, G. and Henner, W.D. (1990) GST1 gene deletion determined by polymerase chain reaction. Nucleic Acids Res., 18, 3670.

[9] Dubeau, L., Chandler, L.A., Gralow, J.R., Nichols, P.W. and Jones, P.A. (1986) Southern blot analysis of DNA extracted from formalin-fixed pathology specimen. Cancer Res., 46, 2964-2969.

[10] Hayashi, S., Watanabe, J. and Kawajiri, K. (1992) High susceptibility to lung cancer analyzed in terms of combined genotypes of P450IAl and Mu-class glutathione Stransferase genes. Jpn. J. Cancer Res., 83, 866-870.

[11] Health and Vital Statistics: 2. Vital Statistics 1992 Republic of China. (1993) Department of Health, the Executive Yuan, Taiwan, ROC.

[12] Hernandez, L., Petropoulos, C.J., Hughes, S.H. and Luinsky, W. (1991) DNA methylation and oncogene expression in methapyrilene-induced rat liver tumors and in treated hepatocytes in culture. Mol. Carcinogenesis, 4, 203-209.

[13] Kaye, F., Battey, J.F., Nau, M.M., Brooks, B., Seifter, E., Degreve, J., Birrer, M.J., Sausville, E. and Minna, J. (1988) Structure and expression of the human L-myc gene reveal a complex pattern of alternative mRNA processing. Mol. Cell Biol., 8, 186-195.

[14] Lafuente, A., Pujol, F., Carretero, P., Villa, J.P. and Cuchi, A. (1993) Human glutathione S-transferase $\mu$ (GST $\mu$ ) deficiency as a marker for the susceptibility to bladder and larynx cancer among smokers. Cancer Lett., 68, 49-54.

[15] Lu, S.H., Hsieh, L.L., Luo, F.C. and Weinstein, I.B. (1988) Amplification of the EGF receptor and c-myc genes in human esophageal cancers. Int. J. Cancer, 42, 502-505.

[16] Mannervik, B., Awasthi, Y.C., Board, P.G., Hayes, J.D., Di Illio, C., Ketterer, B., Listowsky, I., Morgenster, R., Muramatsu, M., Pearson, W.R., Pickett, C.B., Sato, K., Widersten, M. and Wolf, C.F. (1992) Nomenclature for human glutathione transferase. Biochem. J., 282, 305-306.

[17] Raney, K.D., Meyer, D.J., Ketterer, B., Harris, T.M. and Guengerich, F.P. (1992) Glutathione conjugation of aflatoxin $\mathrm{B}_{1}$ exo- and endo-epoxides by rat and human glutathione S-transferases. Chem. Res. Toxicol., 5, 470-478.
[18] Ryberg, D., Heimdal, K., Fossa, S.D., Borresen, A. and Haugen, A. (1993) Rare Ha-ras 1 alleles and predisposition to testicular cancer. Int. J. Cancer, 53, 938-940.

[19] Seidegard, J., Pero, R.W., Miller, D.G. and Beattie, E.J. (1986) Glutathione transferase in human leukocytes as a marker for the susceptibility to lung cancer. Carcinogenesis, 7, 75I-753.

[20] Seidegard, J., Vorachek, W.R., Pero, R.W. and Pearson, W.R. (1988) Hereditary differences in the expression of the human glutathione transferase active on trans-stilbene oxide are due to a gene deletion. Proc. Natl. Acad. Sci. USA, 85 , 7293-7297.

[21] Seidegard, J., Pero, R.W., Markowitz, M.M., Roush, G., Miller, D.G. and Beattie, E.J. (1990) Isozymes(s) of glutathione transferase (class mu) as a marker for the susceptibility to lung cancer: a follow up study. Carcinogenesis, 11, 33-36.

[22] Sheen, I.S., Liaw, Y.F., Chu, C.M. and Pao, C.C. (1992) Role of hepatitis $\mathrm{C}$ virus in spontaneous hepatitis $\mathrm{B}$ surface antigen clearance during chronic hepatitis $B$ virus infection. J. Infect. Dis., 165, 831-834.

[23] Sugimura, H., Caporaso, N.E., Modali, R.V., Hoover, R.N., Resau, J.H., Trump, B.F., Lonergan, J.A., Krontiris, T.G., Mann, D.L., Weston, A. and Harris, C.C. (1990) Association of rare alleles of the Harvey ras protooncogene locus with lung cancer. Cancer Res., 50, 1857-1862.

[24] Tamai, S., Sugimura, H., Caporaso, N.E., Resau, J.H., Trump, B.F., Weston, A. and Harris, C.C. (1990) Restriction fragment length polymorphism analysis of the L-myc gene locus in a case-control study of lung cancer. Int. J. Cancer, $46,411-415$

[25] Taylor, J.A., Bell, D.A. and Nagorney, D. (1993) L-myc proto-oncogene alleles and susceptibility to hepatocellular carcinoma. Int. J. Cancer, 54, 927-930.

[26] Tsai, J.F., Jeng, J.E., Ho, M.S., Chang, W.Y., Lin, Z.Y. and Tsai, J.H. (1994) Hepatitis B and C virus infection as risk factors for hepatocellular carcinoma in Chincsc: a casecontrol study. Int. J. Cancer, 56, 619-621.

[27] Yu, M.W. and Chen, C.J. (1992) Epidemiologic characteristics and risk factors of hepatocellular carcinoma. J. Natl. Publ. Health Assoc. (ROC), 11, 165-187. 